\title{
You Cannot Take War Out of the Soldier
}

\author{
Susanna Hast \\ https://orcid.org/0000-0002-4370-4388
}

\begin{abstract}
This article is an experimentation in poetry on the topic of combat and killing derived from interview data. Such writing is called many things, but I named it documentary poetry which, regardless of its origins, is a manifestation of the indeterminacy and autonomy of art. I have taken the words of Finnish military cadets, poetic in themselves, and exhausted the possibilities of translation by abandoning accuracy for the sake of sensual precision. The zealless yet unsettling depictions of combat are reassembled in poems troubling the mystique and exceptionalism of the military while pointing to the fragility of the military itself.
\end{abstract}

\section{Keywords}

military, investigative poetry, methods of inquiry, killing, combat, arts-based inquiry

\section{Explanations}

As we have seen, the vast majority of soldiers cannot kill in cold blood and need to kill in a de-subjectified state, e.g., in reflexes, rages, and panics. But who does the killing when reflexes, rages, and panics are activated? [ . . . Even when a sense of agency is absent during the rage-induced or reflexcontrolled act of killing, however, a sense of moral responsibility can be produced by a retrospective identification of action and ownership, a retrospective production of the moral sense of agency, even when the practical agent at the time of action was a non-subjective rage or reflex: "Oh my God, look what I've done!” (Protevi, 2013, pp. 130, 132)

This is documentary poetry.

This is poetry based on interviews with first-year cadets of the National Defence University in Finland in 2018 (Hast, 2020a).

Cadet is the military rank of those studying for a bachelor's degree in Military Sciences. After graduation, the cadet becomes lieutenant. The degree is academic but includes practical training in operational skills designed to foster the desire and ability to win battles.

A question was asked. What is the soldier's body like? A second question was asked. What is combat?

A third question was asked. Is combat about killing? It was not asked, but it came up, that soldiers can die in combat.

The conversation about killing in combat made time slow down. Words got stuck in the throat and, I imagine, saliva dried in the mouth. Fingers became restless and pitch of voice changed, bodies tensed, and the euphemisms spoke of "erasures" (Belkin \& Carver, 2012) of the language of violence.

This poetry is imagination.

This poetry tries to capture how soldiers imagine war when war is distant to them.

This poetry speaks of soldiers who want to be soldiers of peace and how, perhaps as consequence, ideas about combat, war, and soldiering are dangerously improvised.

Improvised silence.

Cracking open the mystical box of militarism - the upholding and nurturing of military values, beliefs, and practices which rely on violence as the solution to insecurity.

This poetry is the struggle to articulate that war really does mean killing life.

This poetry has exhausted the possibility of translation. Slang, dialects, gaps, sighs, blurts.

Finnish to English, oh, I could not. 
The voicer of this poetry is a body against which words bounce.

The poet is all body.

Body attentive to language while transmuting.

Channeling because the reader cannot hear the original sound and has to trust the poet's intention even when the poet does not write as $I$.

This poetry is a use of power, but it is certainly nothing compared to military power.

These poems are camouflaged.

How many speakers, even the poet has forgotten but can check if needed.

These poems are made with love and respect.

The meaning of love took another text spoken (Hast, 2020b).

Poetry exists for its own sake, even in a context like this.

Elizabeth Grosz (2008) saying, yes, art intensifies sensations.

Art not a representation. Art not explained, aesthetically evaluated, meanings un-uncovered.

Art of chaos, independent from the creator and perceiver (Grosz, 2008).

These poems are a risk.

"Militaries are a lot more fragile and contingent than elites will admit" (Enloe, 2015, p. 8).

Poems could romanticize and fetishize military bodies, but here we are.

\section{Are You Able to Say It?}

[Soldier body, what could it mean for you?] My own body

but my body is more than a soldier

A soldier body (your soldier body?)

is not only ready to fight and commit violent acts

it is more than that

A soldier body

is more capable

is systematically and consciously prepared

Our capacity to perform -

it is preparing the soldier body specifically for ...

[Capacity for what?]

Capacity to endure

to help

but also ...

I would not like to

... to kill

It feels so ...

so black and white

[Are you able to say it?]

Well, if I think about it

Yes, I can say it

I just saw this talk show

It made me think about this more

[This feels like a difficult topic to talk about. I can see:

Bodies change when I ask about killing they change...

Is the idea of killing too abstract

Or what do you really think about it?

Answer what you think, not what you are supposed to say

You can speak freely now]

In the conditions where soldiers end up in

they have to kill

Who would be better at that than a soldier

Who has the perspective on how and when

I think

we should all think about this more,

what killing means for us, to us

why I would kill

(to protect and defend myself, my family and friends, my country)

When it is necessary

\section{Fear of Death}

Is it about killing?

$$
\text { No... }
$$

you do not have to shoot a single bullet to be in combat to be a combatant 
No one knows what combat would be like

You can try to simulate it

but you can't simulate fear of death

I saw some situations,

what-the-fuck situations,

when someone attacked,

they did not really do anything but

I realized my brain processed it for a while before I did anything

In a real combat situation

I don't know how long the processing time would be

if would I run away, or what I would do

Here you can laugh about it- "Haha, did you get your ass kicked?" -

but fear of death makes it very different

\section{Something that Will Haunt You}

terminal things

final decisions

terminal things take place

there is no undo button, no retake

right and wrong

wrong to take life

right to defend the fatherland

hard to give an answer

when I have not been in that situation

depends on what you have actually done

if it is something that will haunt you

if you fail to act

and as result

end up losing half of your group

if you have murd-

taken the life of

an innocent person

I hope I never encounter such a situation

\section{The Inevitable}

Combat,

Seven seconds of silence

it is a situation no one wants to end up in ...
That is why it is military combat ...

No civilians would be involved

Someone has to make the sacrifice for others

Because it would not be fair

if womenandchildren and old people had to suffer

so it's become "men's work"

Anyone can be made a soldier

But what does it take?

Most do their military service, and then they are supposedly soldiers

\section{I cough, and apologise}

But some decide to let themselves crash after their conscription

and think they don't have to do anything like that again

But the inevitable fact is that

One day war will come

I cough, and cover my mouth, cough some more

Okay, how could I say this elegantly

the

inevitable

fact

war will come one day ... .

It is some kind of a duty

No, not "some kind"

$$
\text { It is all of ours - a duty }
$$

to be able to make sure that

those who do not have to suffer

will not suffer

Well they can still suffer, second-hand

but military force doesn't target them

[Well, all wars include civilian victims. What do you think about being involved in a war with civilian casualties?]

It is inevitable

I am not saying it is right ... it is not right . . but it is inevitable ... it is not justified ... let's say

it might be necessary 
[Have you considered ... that military work might include killing?]

[War time]

War time

You have to make a choice, my life or the other's the other will think the same

you don't necessarily want to be in that position

to take a life

but you just have to think

if I don't shoot

the other will -

that is for sure

There is no situation where

one or other thinks "I won't shoot"

and the other also thinks "I won't shoot"

because then there would be no war

\section{Would Kill a Terrorist}

[Combat]

It has a mental and physical side.

Tough, really tough

[On the march,

I threw another word to go with combat: killing

What do you think of that?]

Sounds a bit fierce

$$
\text { If necessary, if demanded }
$$

[You are sold-]

In extreme conditions,

it can be done

For sure

Has to be done

$$
\text { True }
$$

I value life that much

I'd rather fire first than be shot

Kill or be killed
Hah

But we are talking about war otherwise I would not killunder no circumstances

and even in

war you think about it for a long time

[Well, do you ever think about it?

$<$ My voice gets tense and louder

Isn't that why you are here?]

Has crossed my mind

I don't even know what my task would be

In one group

Killing would be quite unlikely for me

I would likely witness a bombing from above

I have thought about what war would be like

If I think about the terrorist acts

I would not hesitate one moment about killing a terrorist

That is for sure

For the common good

I would too.

I would sacrifice myself.

Sounds a bit heroic now, hah

We are trained to think with our brains

We are not here for our own benefit

this is altruistic

Killing has a lot to do with-

It is not personal

I don't know the person

It is not personal

It is not the same as stabbing on the street

I would run in that situation

but in war it is different

In an extreme situation

99 percent of us can do it

I cannot say everyone can

But I am quite sure we can all do it

if it is kill or be killed

I do not know about my future

But I have thought about it 
[I wonder if this topic is not really dealt with here]

No, it is not bypassed

when we go shooting at the rifle range

we are thinking about the war context

We are not trained as shooters on a range

but soldiers

We are simulating real situations,

we use battle gear

There is always some reference to the real situation

It is in the background

We don't associate killing with torture or anything like that

It is stopping aggression

Avoiding casualties

It is about stopping

We are talking about the Defence Forces

But remembering we are facing other human beings,

and we are human beings too

We have not forgotten this

We all know what we are here for

\section{Someone Always Dies}

It has to be done (it is an assignment)

Sometimes you need to destroy the enemy

Then you do it

This is what I think

$$
\text { as a soldier }
$$

[Does it mean killing?]

It has to mean someone dies

I have never heard of combat where no one dies

\section{When Your Flesh is Torn}

a soldier's body is injured

the self with bullet holes

occupational hazard but i rarely think about it enemies die, but not me "my wishes"

$\mathrm{i}$ have thought a lot about war, about death, about friends dying, enemies dying,

even my family dying, but not me

it was sobering

we are all vulnerable

in the end, it matters very little how determined you are mentally

when your flesh is torn

for even a regular person

what do i leave behind?

\section{His Body Tenses and He Massages His Fingers}

it was confusing

that $\mathrm{i}$ had not thought about it

dying,

if $i$ have thought about it,

Dying

$i$ have not imagined my wishes

the words i want to leave to my closest ones

to my closest one

about myself

it was moving, the entire atmosphere

i think for most of us

for me it was the first time to write such a letter

it was moving

[okay, so thank y-]

and then

[yes?]

those words were difficult to write

even if it was not real

how they still were

m-y-y own

it was just an exercise collectively

but individually

it came from my heart, really

not words on a paper for the sake of putting words on paper

it moved something inside me 


\section{References}

Belkin, A., \& Carver, T. (2012). Militarized masculinities and the erasure of violence. International Feminist Journal of Politics, 14(4), 558-567. https://doi.org/10.1080/14616742.2012.726099

Enloe, C. (2015). The recruiter and the sceptic: A critical feminist approach to military studies. Critical Military Studies, 1(1), 3-10. https://doi.org/10.1080/23337486.2014.961746

Grosz, E. (2008). Chaos, territory, art: Deleuze and the framing of the earth. Columbia University Press.

Hast, S. (2020a). Synching the martial body: Poetic encounters with Finnish cadets. Critical Military Studies, 1-24. https://doi.org/10.1080/23337486.2020.1861738

Hast, S. (2020b). Walking with soldiers: How I learned to stop worrying and love cadets. Journal for Artistic Research, 21. https://doi.org/10.22501/jar.700528

Protevi, J. (2013). Affect, agency, and responsibility: The act of killing in the age of cyborgs. In K. McSorley (Ed.), War and the Body: Militarisation, practice and experience (pp. 128-137). Routledge. 